\title{
The Impact of Grazing on Plant Natural Regeneration in Northern Slopes of Mount Kilimanjaro, Tanzania
}

\author{
Imani Abinery Kikoti ${ }^{1}$, Cosmas Mligo², Dominico Benedicto Kilemo ${ }^{3 *}$ \\ ${ }^{1}$ Tanzania National Parks, Arusha, Tanzania \\ ${ }^{2}$ Department of Botany, University of Dar es Salaam, Dar es Salaam, Tanzania \\ ${ }^{3}$ Sokoine University of Agriculture, Morogoro, Tanzania \\ Email: ${ }^{\text {dbkilemo@yahoo.com }}$
}

Received 25 April 2015; accepted 5 June 2015; published 8 June 2015

Copyright (C) 2015 by authors and Scientific Research Publishing Inc.

This work is licensed under the Creative Commons Attribution International License (CC BY). http://creativecommons.org/licenses/by/4.0/

c. (i) Open Access

\begin{abstract}
Livestock grazing is considered to be of great ecological importance in terrestrial ecosystems if sustained at acceptable levels. Overgrazing has ecological ramifications which lead to degradation of the ecosystem. This has become a problem in many parts of Tanzania. A study was conducted in Northen Slopes of Mount Kilimajaro in order to examine the impact of grazing on natural regeneration of the grazed vegetation. This paper is guided by the hypothesis that the species richness, species diversity and density of regenerants vary across grazing intensities. The study area was divided into four zones as per grazing intensity namely heavily grazed areas, moderately grazed, least grazed and ungrazed areas. Ten rectangular quadrats of $20 \mathrm{~m} \times 25 \mathrm{~m}$ were established in each zone, making a total of $\mathbf{4 0}$ quadrats in the entire study area. A stratified random sampling procedure was used in locating quadrats in each zone of grazing intensity whereby two subquadrats of $2 \mathrm{~m} \times 5 \mathrm{~m}$ were nested in bigger quadrats. Natural regeneration was assessed in terms of species diversity and density of seedlings, saplings and poles. Results indicate that species regeneration varied among areas with different grazing intensity. The variations of seedlings and saplings density among areas with different grazing intensity were statistically significant. The species diversity of regenerants differed significantly among areas with different grazing intensity. Keeping the grazing intensity at low and moderate levels will stimulate more plant growth and diversity as opposed to heavy grazing which will lead to vegetation retrogression.
\end{abstract}

\section{Keywords}

Impact of Grazing, Vegetation Ecology, Mount Kilimanjaro

\footnotetext{
${ }^{*}$ Corresponding author.
}

How to cite this paper: Kikoti, I.A., Mligo, C. and Kilemo, D.B. (2015) The Impact of Grazing on Plant Natural Regeneration in Northern Slopes of Mount Kilimanjaro, Tanzania. Open Journal of Ecology, 5, 266-273. 


\section{Introduction}

The northern slopes of Mount Kilimanjaro have been facing grazing pressure resulting from increased livestock population in the area [1]. This is because of land use changes associated with the increase in land under cultivation and settlements at the expense of a decrease of pastoral lands. Moreover, due to extended periods of drought, the area has been characterized by short rains and delayed long rains, such that pastoral communities from both Tanzanian and Kenyan sides have been driving their livestock to montane forests in search for forage and water. Grazing may have been affecting plant composition and interfering with natural regeneration. Variation in grazing intensities among parts of the montane forests based on accessibility and protection status may also reflect variation on vegetation response. The literature on impact of grazing in Mount Kilimanjaro ecosystem is scant. At present there is no any documented study on this topic. It is within this context the paper was conceptualized. The paper is guided by the hypothesis that species richness, species diversity and density of regenerants differ across grazing intensities.

\section{Materials and Methods}

\subsection{The Study Area}

Mount Kilimanjaro is found on the Northern Tanzania, adjacent to Tanzania-Kenya international boundary (Figure 1). Geographically, it lies at $2^{\circ} 45^{\prime}-3^{\circ} 25^{\prime}$ South and $37^{\circ} 00^{\prime}-37^{\circ} 43^{\prime}$ East about $300 \mathrm{Km}$ south of the equator [1]. The mountain is surrounded by Moshi, Rombo, Hai and Siha districts that are in Kilimanjaro Region on the southern, eastern, south-western and north-western slopes respectively and Longido District which belongs to Arusha Region on the northern slopes. Mount Kilimanjaro ecosystem is a protected area under Tanzania National Parks (TANAPA)

The conservation history of Mount Kilimanjaro dates back in early 1900s when it was gazetted as Game Reserve and as a forest reserve in 1921 [2]. The upper part of Mount Kilimanjaro was upgraded as National Park in 1973 starting from tree line (2700 m above sea level) and above having an area of $756 \mathrm{~km}^{2}$ by Government Notice No. 50 of March 16, 1973 in accordance with the National Parks Ordinance (Cap 412) of 1959 [2]. The

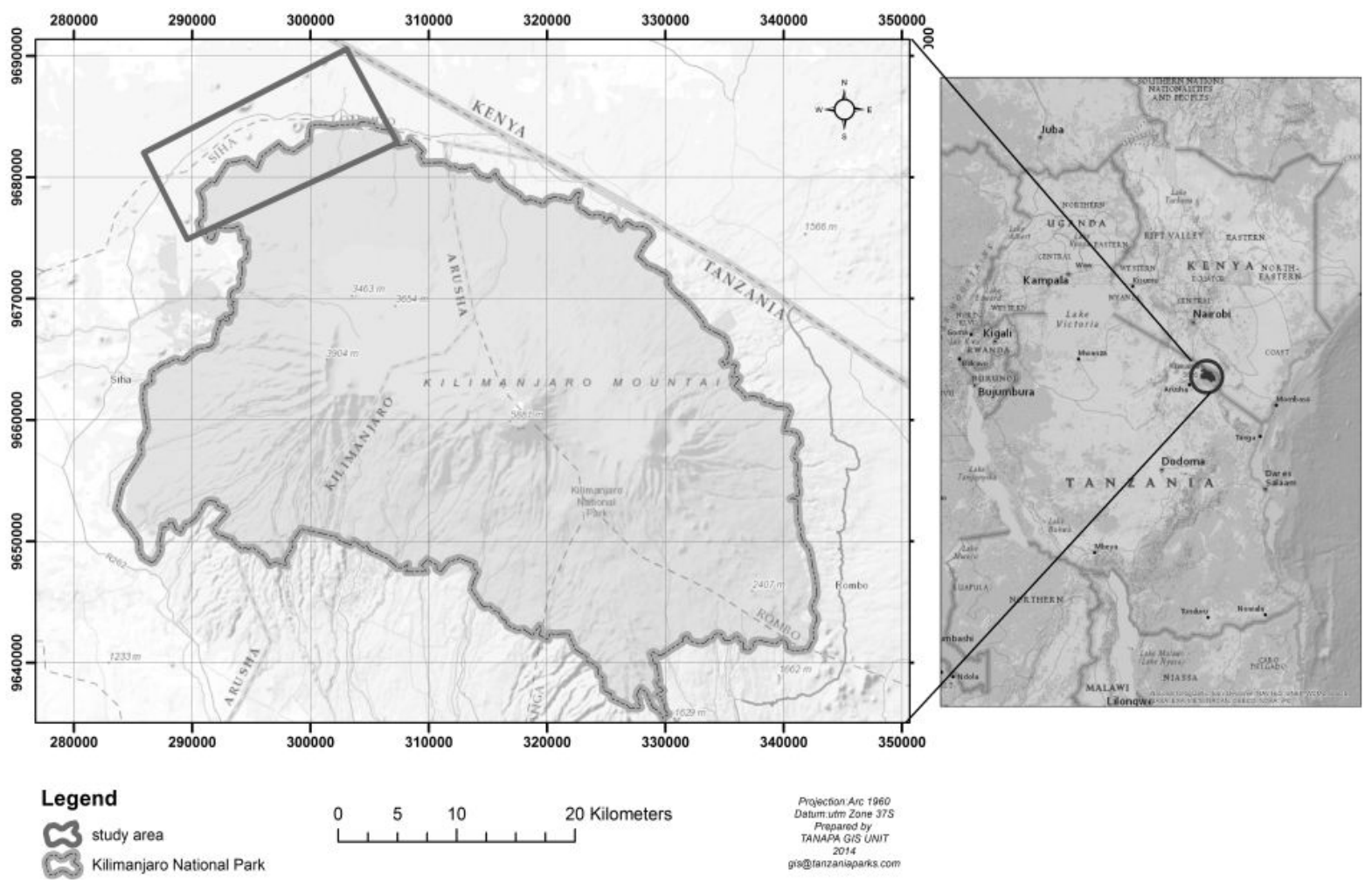

Figure 1. Map showing the location of study area in Mount Kilimanjaro. 
montane forest was under Forest and Beekeeping Department (FBD). Mount Kilimanjaro was inscribed by UNESCO as World Heritage Site in 1987 based on high fauna and flora diversity. In September 2005, the Park's boundaries were adjusted to include Kilimanjaro Forest Reserve $\left(1078.28 \mathrm{~km}^{2}\right)$, thus the total area increased to $1834 \mathrm{~km}^{2}$ [2].

\subsubsection{Climate}

The climate of Mount Kilimanjaro varies from one ecological zone to another based on altitude, gradient and aspect. The montane forest that surrounds the mountain at altitude of 1600 - 2400 m.a.s.l on northern slopes and 1600 - 2800 m.a.s.l. on the southern slopes is characterized by a typical equatorial climate [1]. There are two distinct rainy seasons in this forest, the long rainy period occurs between March and May whereas the short rain periods occurs between November-December hence climate of the area being bimodal. The average annual rainfall reaches a maximum of $3000 \mathrm{~mm}$ at 2100 m.a.s.l. on the central southern slopes in the lower part of the montane forest belt, and therefore exceeding an average precipitation of typical African high mountains [3]. However, rainfall and temperature vary with altitude and exposure to the wind direction blowing from the Indian Ocean. The mean annual precipitation decreases to less than $500 \mathrm{~mm}$ above $4000 \mathrm{~m}$ in the alpine zone. The northern slope, on leeward side receives much less rainfall [3]. The mean annual temperature at the foot of the mountain particularly in Moshi ( $813 \mathrm{~m}$ a.s.l.) is $23.4^{\circ} \mathrm{C}$ [3] It decreases to $18^{\circ} \mathrm{C}$ at $1500 \mathrm{~m}, 9.2^{\circ} \mathrm{C}$ at $3100 \mathrm{~m}$, $4.5^{\circ} \mathrm{C}$ at $4000 \mathrm{~m}$ [4]. At the top of Kibo at altitude of $5800 \mathrm{~m}$ the temperature decreases up to $-7.1^{\circ} \mathrm{C}$ [5] with a lapse rate of decrease about $0.56^{\circ} \mathrm{C}$ per $100 \mathrm{~m}$ [4]. The climate in the alpine belt above 3500 to $4000 \mathrm{~m}$ is characterized by nightly frosts all the year round. The belt has intensive sunshine during day time; it is summer during day time and winter during night [3].

\subsubsection{Local Communities}

Majority of local communities bordering Mount Kilimanjaro are crop cultivators. These are mostly in Moshi rural, Hai, Siha and Rombo districts located in the southern, western and eastern sides of the Mountain. The major dominant form of agriculture in these districts is Agroforestry popularly known as "Chaga home gardens". Agro-pastoralists are only found in Longido District which is located on the leeward side of Mountain in the northern slopes.

\subsection{Data Collection}

\subsubsection{Reconnaissance Survey}

Preliminary survey was first carried out in montane forest of the northern slopes of Mount Kilimanjaro to define vegetation segments based on its homogeneity and grazing intensity. This was followed by zoning the area based on grazing intensities into heavily grazed areas, moderately grazed, least grazed and ungrazed areas. These areas were used for detailed study on natural regeneration pattern.

\subsubsection{Vegetation Sampling Procedures}

The sampling strategy was based on the four grazing intensities (i.e. heavily grazed, moderately grazed, least grazed and ungrazed). Ten rectangular quadrats of $20 \mathrm{~m} \times 25 \mathrm{~m}$ were established in each category, making a total of 40 quadrats in the entire study area. A stratified random sampling procedure was used in locating quadrats in each category of grazing intensity. Two subquadrats of $2 \mathrm{~m} \times 5 \mathrm{~m}$ were nested in bigger quadrats as recommended by [6]. The tree seedlings were plants classified at growth stage with $<2 \mathrm{~cm}$ diameter, saplings are plants with $2-4 \mathrm{~cm}$ diameters and poles are stems at growth stage with $4-9 \mathrm{~cm}$ diameter as pointed out by [7]. Also grasses and herbaceous layer was determined by using three $1 \mathrm{~m}^{2}$ quadrats nested in $20 \mathrm{~m} \times 25 \mathrm{~m}$ quadrats and the percentage of plant species cover was estimated in each quandrat. All plants were identified to species level when it was possible in the field, otherwise specimens of plant species that were not easily identified in the field, specimens were collected, pressed and taken to the herbarium in the Department of Botany, University of Dar es Salaam (DSM) for identification by matching with the herbarium specimens and/or keying using relevant floras such as Flora of Tropical East Africa (FTEA) and Flora Zambeziaca (FZ) (Plate 1).

\subsubsection{Assessment of Grazing Intensity}

The degree of livestock trampling was assessed by measuring percentage (by area) of trail and bare ground in 
each $20 \mathrm{~m} \times 25 \mathrm{~m}$ quadrat. Qualitative estimation of grazing intensity in each quadrat based on assessment of percentage utilization of vegetation by livestock was also done in each quadrat. A total of 3 grazing intensity classes based on the modified [8] classification system were established as shown in Table 1.

\subsection{Data Analysis}

Plant natural regeneration was assessed in terms of species richness, species diversity and density of seedlings, saplings and poles. Species richness was analyzed through counting the total number of species found in each quadrant under a given grazing intensity. The plant species diversity was determined from raw data by using the Shannon's diversity index $\left(H^{\prime}\right)[9]$ according to the formula below:

$$
H^{\prime}=-\sum_{i=1}^{S}\left(p_{i} \ln p_{i}\right)
$$

where:

$p_{i}=n_{i} / N$, the number of individuals found in the $i$ th species as a proportion of total number of individuals found in all the species.

In = Natural logarithms to base $e$

The plant species evenness $(E)$ of each area was calculated using the sample formula below (Alatalo, 1981).

$$
\text { Evenness }(E)=\frac{H^{\prime}}{\ln S}
$$

where $H^{\prime}$ Shannon-Wiener Diversity Index and $S$ is the total number of species (from the selected study sites.

One-way ANOVA was used to test the statistical significance of the observed differences across grazing intensities. The significance level for all tests was based on $5 \%$ critical limit.

\section{Results}

\subsection{Effects of Grazing Intensity on Density of Tree Regenerants}

Natural tree species regeneration varied among areas with different grazing intensity, where the Least grazed

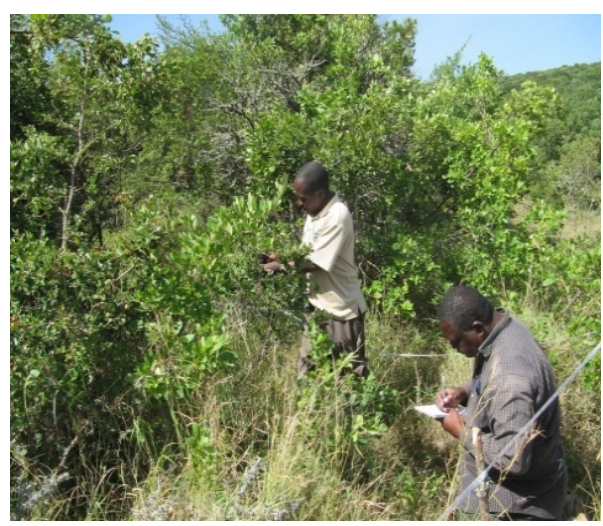

(a)

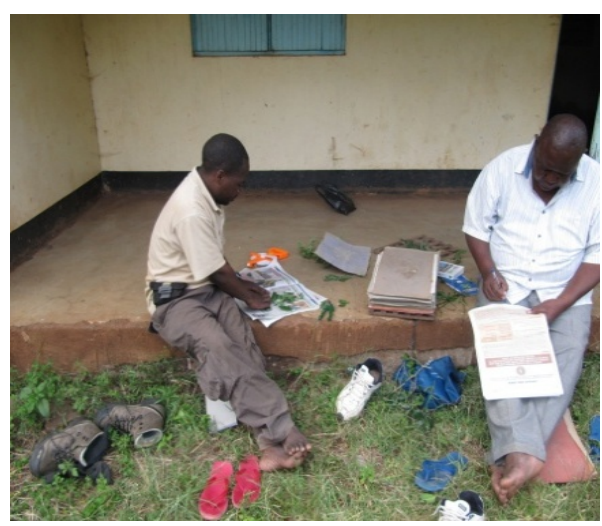

(b)

Plate 1. Photo showing (a) established study plot for vegetation sampling and (b) pressing unidentified plant species at Lerangw’a rangers post.

Table 1. Grazing intensity classes and their interpretation.

\begin{tabular}{cc}
\hline Grazing intensity class & Interpretation \\
\hline 0 & No grazing \\
1 & $1 \%-20 \%$ : Least grazed \\
2 & $21 \%-60 \%$ : Moderately grazed \\
3 & $61 \%-100 \%$ : Heavily grazed \\
\hline
\end{tabular}


areas had the highest density of regenerants (seedlings, saplings and poles) with a total of 27,150 stems/ha (Figure 2(b)). This was followed by the ungrazed areas with 22,550 stems/ha and the moderately grazed areas had 10,250 stems/ha (Plate 2, Figure 2(a) and Figure 2(c)). With a total of 9750 stems/ha of regenerants (seedlings, saplings and poles) in heavily grazed areas, this was the lowest density of regenerants (Figure 2(d)).

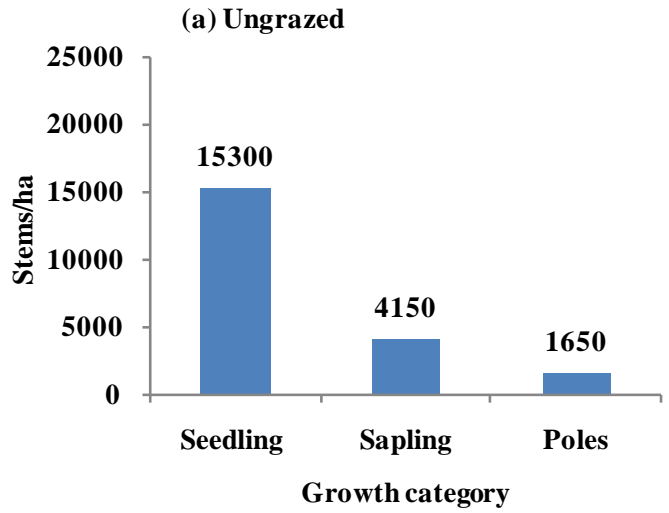

(c) Moderately grazed

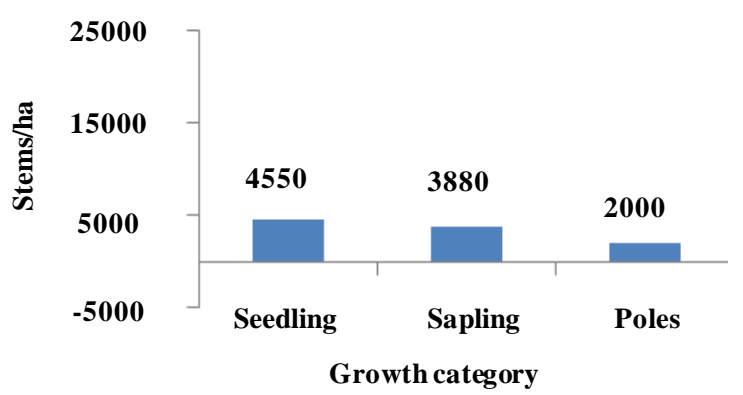

(b) Least grazed

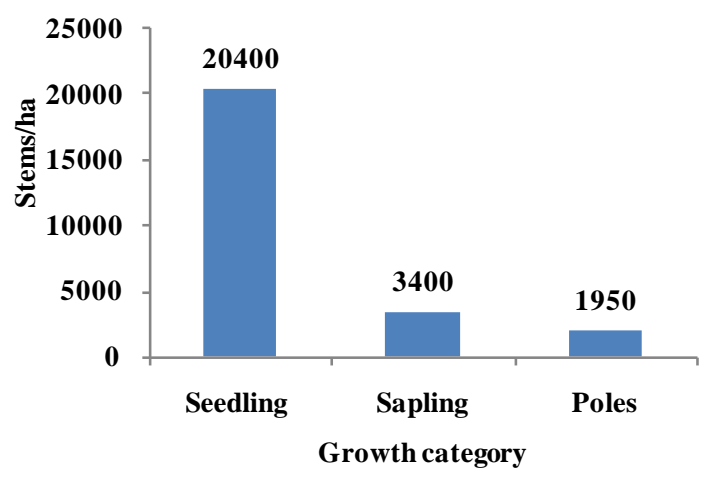

(d) Heavily grazed

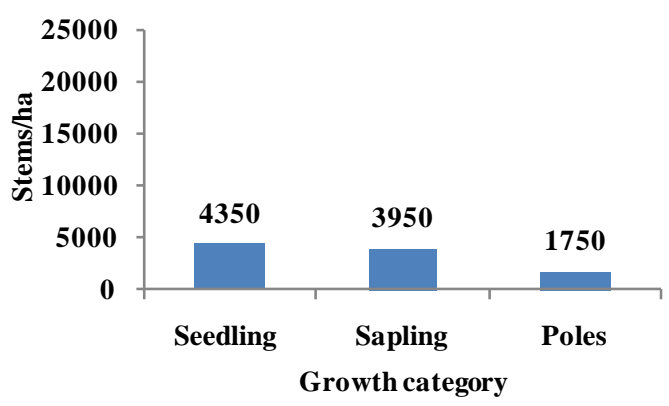

Figure 2. Variation in tree species regeneration patterns among areas with different grazing intensities in the montane forests of Northern slopes of Mount Kilimanjaro.

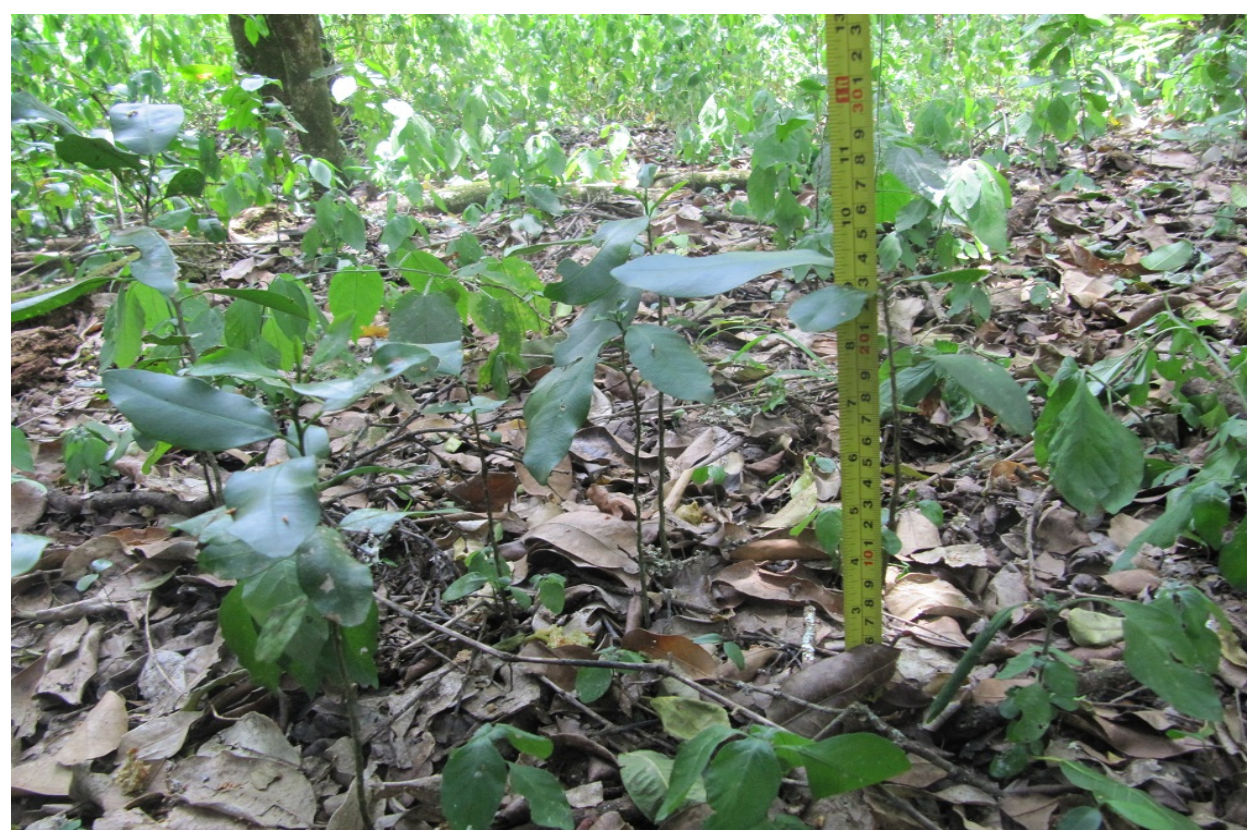

Plate 2. Regenerants in ungrazed areas (The seedling of Teclea simplicifolia). 
The variations of seedlings and saplings density (stems/ha) among areas with different grazing intensities were statistically significant at $\mathrm{p}<0.05$ (Table 2). Based on Tukey Honest Significant Difference (HSD), least grazed vs heavily, least grazed vs moderately grazed, ungrazed vs heavily and ungrazed vs moderately grazed areas were statistically significant in terms of seedlings density (Table 2). However, the significant difference existed on sapling density only between least and moderately grazed areas. The density of poles had no statistical significant difference among areas with different grazing intensities at $\mathrm{p}>0.05$ (Table 2).

\subsection{Effects of Livestock Grazing on Species Diversity of Regenerants}

The species diversity of regenerants differed significantly among areas with different grazing intensity based on Analysis of Variance (ANOVA) $(\mathrm{F}=11.8095, \mathrm{p}=0.000016)$. Multiple comparison test based on Tukey HSD test showed the statistical significant differences existed between least grazed vs heavily grazed, least vs ungrazed, moderately grazed vs heavily grazed and moderately grazed vs ungrazed areas (Table 3).

\subsection{Effects of Livestock Grazing on Species Richness of Regenerants}

The difference in species richness of regenerants among areas with different grazing intensity was significant based on Analysis of Variance (ANOVA) $(\mathrm{F}=10.53775, \mathrm{p}=0.000041)$. Multiple comparison test based on Tukey HSD test showed that the least and moderately grazed areas had significantly higher number of species than heavily and ungrazed areas (Table 4).

Table 2. Multiple comparison test of variation in regenerant density (stems/ha) among areas with different grazing intensities in the montane forests of Northern slopes of Mount Kilimanjaro (Letters above number indicates statistically significant at $\mathrm{p}$ $<0.05)$.

\begin{tabular}{cccccccccccccc}
\hline & \multicolumn{3}{c}{ Seedlings } & \multicolumn{4}{c}{ Saplings } & \multicolumn{3}{c}{ Poles } \\
\hline Grazing intensity & A & B & C & d & a & b & c & d & A & b & c & D \\
\hline Heavily (a) & - & $0.0002^{\mathrm{ab}}$ & 0.9969 & $0.0008^{\text {ad }}$ & - & 0.92 & 0.06 & 0.77 & - & 0.5 & 0.7 & 1.0 \\
Least (b) & - & - & $0.0002^{\mathrm{bc}}$ & 0.3045 & - & - & $0.01^{\mathrm{bc}}$ & 0.39 & - & - & 1.0 & 0.3 \\
Moderately (c) & - & - & - & $0.0013^{\text {cd }}$ & - & - & - & 0.36 & - & - & - & 0.4 \\
Ungrazed (d) & - & - & - & - & - & - & - & - & - & - & - & - \\
\hline
\end{tabular}

Table 3. Variation of diversity of tree regenerants among areas with different grazing intensities $(\mathrm{M}=\mathrm{Mean} \pm \mathrm{Standard}$ Error and letters ${ }^{\mathrm{a}, \mathrm{b}, \mathrm{c}, \mathrm{d}}$ indicates statistical level of significance at $\mathrm{p}<0.05$ ).

\begin{tabular}{ccccc}
\hline Level of grazing & Heavily $^{\mathrm{a}} \mathrm{M}=1.2 \pm 0.07$ & Least $^{\mathrm{b}} \mathrm{M}=1.69 \pm 0.098$ & Moderately $^{\mathrm{c}} \mathrm{M}=1.78 \pm .099$ & Ungrazed $^{\mathrm{d}} \mathrm{M}=1.1 \pm 0.11$ \\
\hline Heavily $^{\mathrm{a}}$ & - & 0.006353 & 0.001148 & 0.920141 \\
Least $^{\mathrm{b}}$ & - & - & 0.916979 & 0.001175 \\
Moderately $^{\mathrm{c}}$ & - & - & - & 0.000301 \\
Ungrazed $^{\mathrm{d}}$ & - & - & - & - \\
\hline
\end{tabular}

Table 4. Variation of species richness of tree regenerants among areas with different grazing levels $(\mathrm{M}=\mathrm{Mean} \pm \mathrm{Standard}$ Error and letters $\mathrm{s}^{\mathrm{a}, \mathrm{b}, \mathrm{d}, \mathrm{d}}$ indicates statistical level of significance at $\mathrm{p}<0.05$ ).

\begin{tabular}{|c|c|c|c|c|}
\hline Level of grazing & Heavily $^{\mathrm{a}} \mathrm{M}=3.9 \pm 0.31$ & Least $^{\mathrm{b}} \mathrm{M}=8.4 \pm 0.78$ & Moderately $^{\mathrm{c}} \mathrm{M}=7.3 \pm 0.86$ & Ungrazed $^{\mathrm{d}} \mathrm{M}=4.8 \pm 0.49$ \\
\hline Heavily $^{\mathrm{a}}$ & - & $0.000259^{\mathrm{a}}$ & 0.003805 & 0.760216 \\
\hline Least $^{\mathrm{b}}$ & - & - & 0.630283 & $0.002116^{\mathrm{b}}$ \\
\hline Moderately $^{\mathrm{c}}$ & - & - & - & $0.046103^{\mathrm{c}}$ \\
\hline Ungrazed $^{\mathrm{d}}$ & - & - & - & - \\
\hline
\end{tabular}




\section{Discussion}

There was significant difference in trees regeneration among areas with different grazing intensities (Figure 2, Table 2). The number of seedlings was significantly higher in the least and ungrazed areas than heavily and moderately areas (Figure 2). High proportion of seedlings in the least and ungrazed areas is an indication of an ongoing natural seedling recruitment (Figure 2(a) and Figure 2(b)). However, the lower proportions of seedlings in heavily grazed and moderately grazed areas shows a restricted tree seedlings recruitments presumably due to effects of livestock grazing (Figure 2(c) \& Figure 2(d)). This is because in this area tree seedlings are being grazed and browsed or trampled by livestock, leading to failure in their natural regeneration patterns. When this happens for the long term, the mortality of old trees are not replaced by the new recruitments causing changes in plant age structure which may be skewed towards ageing individual trees. Based on these facts, the heavily grazed areas may be considered as unhealthy habitats due to unsuccessful natural regeneration of tree species. Similar results were observed in Church forests of Ethiopia where grazing had strong effects on tree seed germination, seedling survival and growth [10]. Also [11] pointed out that livestock grazing destroys seeds including the newly established seedlings thus undermining natural regeneration of trees in Swiss Jura Mountains. Many studies have documented the negative impacts of grazing pressure that results into the natural regeneration failure [12]-[14]. There is no doubt that grazing intensity has negative impacts on natural regeneration pattern in the montane forests of the northern slopes of Mount Kilimanjaro.

In terms of diversity among natural regenerants, the least and moderately grazed areas had the higher diversity of regeneration potential than ungrazed and heavily grazed areas (Table 3). This finding indicates that livestock grazing may be one of the factors facilitating plant species regeneration in least and moderately grazed areas mainly due to the role it plays in reducing competition through grazing and browsing which promotes plant species diversity. This is consistent with the observation made by [15] that low level of livestock grazing increases natural regeneration through reducing competition among plant species in a community. This study observed low diversity of regenerants in ungrazed areas (Table 3). High canopy cover in ungrazed areas may be limiting regeneration of light dependent plants leading to overall low diversity of regenerants. High regeneration of light dependent plants was also observed in Nepal as result of forest gap effects [16]. [17] found that tree species richness was higher in the gap than in the intact vegetation in broad leaved forest in the southern China. The low diversity in heavily grazed areas indicates the role of livestock in hampering regeneration patterns.

From this study various communities regenerated differently due to different levels of grazing intensities. In heavily grazed areas, Euclea spinarum and Carissa spinarum had high density of regenerants than other areas. There was also successful regeneration of E. divinorum in heavily grazed areas since it is unpalatable and hence it was one of the least affected species by livestock grazing. E. divinorum has high concentrations of condensed tannins, as well as total phenolic compounds in their leaves thus bearing lower acceptability of its foliage by most herbivores [18]. This result concurs with the finding by [19] that Euclea sp. was not browsed in heavily grazed areas and it was concluded that large herbivores have little effect on its mortality rates. [20] suggested that E. divinorum may play important roles as a pioneer species in degraded habitats when conditions are suitable. It can also be established in habitats that have not previously supported woody plants species such as grasslands communities and may also promote establishment of other forest trees.

\section{Conclusion}

This study found significant difference in plant natural regeneration pattern among areas with different grazing intensity in the Northern slopes of Mount Kilimanjaro. Moderately grazed areas had the highest plant species diversity complying with intermediate disturbance hypothesis. However, low tree species richness and lack of old aged stands in heavily grazed areas indicated the impacts of livestock grazing which contributed to prevention of trees to attain large size classes. The lowest regeneration potential in heavily grazed areas is an indication of unhealthy ecosystem.

\section{References}

[1] Lambretchs, C., Woodley, B., Hemp, A., Hemp, C. and Nnyiti, P. (2002) Aerial Survey of the Threats to Mount Kilimanjaro Forests. UNDP, Dar es Salaam, 33 p.

[2] Tanzania National Parks (2006) General Management Plan for Kilimanjaro National Park (2006-2015). Tanzania National Parks, Arusha. 
[3] Hemp, A. (2005) Climate Change Driven Forest Fires Marginalizes the Ice Cap Wasting on Mount Kilimanjaro. Global Change Biology, 11, 1013-1023. http://dx.doi.org/10.1111/j.1365-2486.2005.00968.x

[4] Hemp, A. (2005) The Impact of Fire on Diversity, Structure and Composition of Mount Kilimanjaro Vegetation. In: Spehn, E., Liberman, M. and Korner, C., Eds., Land Use Change and Mountain Biodiversity, CRC Press LLC, Boca Raton, 51-68.

[5] Thomson, L.G., Mosley-Thomson, E., Davis, M.E., Henderson, K.A., Brecher, H.H., Zagorodnov, V.S., Mashiotta, T.A., Lin, P.N., Mikhalenko, V.N., Hardy, D.R. and Beer, J. (2002) Kilimanjaro Ice Core Records: Evidence of Holocene Climate Change in Tropical Africa. Science, 298, 589-593. http://dx.doi.org/10.1126/science.1073198

[6] Stohlgren, T.J., Falkner, M.B. and Schell, L.D. (1995) A Modified-Whittaker Nested Vegetation Sampling Method. Vegetatio, 117, 113-121. http://dx.doi.org/10.1007/BF00045503

[7] Mligo, C., Lyaruu, H.V.M. and Ndangalasi, H.J. (2011) The Effect of Anthropogenic Disturbances on Population Structure and Regeneration of Scorodophloeus fischeri and Manilkara sulcata in Coastal Forests of Tanzania. Southern Forests, 73, 33-40.

[8] Rulangalanga, Z.K. (2000) Obstacles to the Sustainable Utilization of the Vegetation of Semi-Arid Areas of Mbulu District for Animal Husbandry. Workshop on Current Initiative in Sustainable Management of Dryland Biodiversity, Arusha. (Unpublished)

[9] Shannon, C. (1948) A Mathematical Theory of Communication. Bell System Technical Journal, 27, 379-423.

[10] Wassie, A., Sterck, F.J., Teketay, D. and Bongers, F. (2009) Effects of Livestock Exclusion on Tree Regeneration in Church Forests of Ethiopia. Forest Ecology and Management, 257, 765-772. http://dx.doi.org/10.1016/j.foreco.2008.07.032

[11] Smit, C., Gusberti, M. and Müller-Schärer, H. (2006) Safe for Saplings; Safe for Seeds? Forest Ecology and Management, 237, 471-477. http://dx.doi.org/10.1016/j.foreco.2006.09.069

[12] Stern, M., Quesada, M. and Stoner, K.E. (2002) Changes in Composition and Structure of a Tropical Dry Forest Following Intermittent Cattle Grazing. International Journal of Tropical Biology, 50, 1021-1034.

[13] Jimenez, J., Jurado, E., Aguirre, O. and Estrada, E. (2005) Effect of Grazing on Restoration of Endemic Dwarf Pine (Pinus culminicola Andresen et Beaman) Populations in Northeastern Mexico. Restoration Ecology, 13, 103-107. http://dx.doi.org/10.1111/j.1526-100X.2005.00012.x

[14] Teich, I., Cingolani, A.M., Renison, D., Hensen, I. and Giorgis, M.A. (2005) Do Domestic Herbivores Retard Polylepis australis Bitt. Woodland Recovery in the Mountains of Cordoba Argentina? Forest Ecology and Management, 219, 229-241. http://dx.doi.org/10.1016/j.foreco.2005.08.048

[15] McEvoy, P.M., McAdam, J.H., Mosquera-Losada, M.R. and Rigueiro-Rodri-Guez, A. (2006) Tree Regeneration and Sapling Damage of Pedunculate Oak Quercus robur in a Grazed Forest in Galicia, NW Spain: A Comparison of Continuous and Rotational Grazing Systems. Agroforestry System, 66, 85-92. http://dx.doi.org/10.1007/s10457-005-2916-0

[16] Sapkota, I.P., Tigabu, M. and Odén, P.C. (2009) Species Diversity and Regeneration of Old-Growth Seasonally Dry Shorea robusta Forests Following Gap Formation. Journal of Forestry Research, 20, 7-14. http://dx.doi.org/10.1007/s11676-009-0002-6

[17] Zang, R.G. and Wang, B.S. (2002) Study on Canopy Disturbance Regime and Mechanism of Tree Species Diversity Maintenance in the Lower Subtropical Evergreen Broad-Leaved Forest, South China. Plant Biosystems, 136, 241-250. http://dx.doi.org/10.1080/11263500212331351149

[18] Fornara, D.A. and DuToit, J.T. (2008) Browsing-Induced Effects on Leaf Litter Quality and Decomposition in a Southern African Savanna. Ecosystems, 11, 238-249. http://dx.doi.org/10.1007/s10021-007-9119-7

[19] Smith, T.M. and Goodman, P.S. (1987) Successional Dynamics in an Acacia Nilotica-Euclea Divinorum Savannah in Southern Africa. Journal of Ecology, 75, 603-610. http://dx.doi.org/10.2307/2260192

[20] Sharam, G., Sinclair, A.R.E. and Turkington, R. (2006) Establishment of Broad-Leaved Thickets in Serengeti, Tanzania: The Influence of Fire, Browsers, Grass Competition, and Elephants. Biotropica, 38, 599-605. http://dx.doi.org/10.1111/j.1744-7429.2006.00195.x 